\title{
The Importance of Whole Language Approach in Teaching English to Intermediate Iranian EFL Learners
}

\author{
Javad Nabizadeh Moghadam \\ Azad University of Torbat Heydariye, Iran \\ Email: fravahr47@yahoo.com \\ Seyyed Mohammad Reza Adel \\ Ferdowsi University of Mashhad, Iran \\ Email: adelzero@yahoo.co.uk
}

\begin{abstract}
The main objective of this study is to emphasize on whole language approach developing mainly the two primary skills of reading and writing in varying degrees and combinations. Based on a language proficiency test, out of 150 senior EFL learners from Azad University of Torbat Heydariye, 90 were chosen and defined as intermediate learners. Two expository reading and writing tests were taken and the results were compared with four reading and four writing scores which were defined as their general reading and writing scores. The results were analyzed using the SPSS software and some correlation and ANOVA analyses were run. The correlation coefficients along with the scatter plot matrix showed strong, weak and in some cases partial correlations among the scales. The results of the post hoc tests of the repeated measures of ANOVA and the pairwise comparison of the measures also showed that the EFL learners performed almost equally well on the skills of reading and writing, but with expository writing and expository reading texts the performance was quite different. The concept of language proficiency was reconsidered in respect to the integrative approach's principles and some pedagogical implications in the field of language teaching were suggested.
\end{abstract}

Index Terms - whole language approach, reading, writing, intermediate learners

\section{INTRODUCTION}

If the aim of language teaching and learning is to develop learners' communicative competence, a whole language approach whereby all the skills are treated in a more interrelated way, should be at the heart of L2 classes and, whenever possible, they should be integrated as happens in actual language use. Teaching language as communication calls for an approach which brings linguistic skills and communicative abilities into close association with each other. One way to obtain this association is by using an integrated approach which gives the students greater motivation that converts to better retention of all the principles related to language learning (speaking, listening, reading, and writing).

This study seeks to answer the question of whether skills being taught are used in isolation or integrated with other skills. As Oxford (1990, pp. 5-6) maintains, "acquiring a new language necessarily involves developing the four primary skills of listening, reading, speaking and writing in varying degrees and combinations. These four skills also include associated skills, such as knowledge of vocabulary, spelling, pronunciation, syntax, meaning, and usage". Thus, the skill strand of the tapestry, as Oxford put it, can lead to effective EFL communication when all the skills are interwoven during instruction.

We have taken reading and writing skills as the main concern of this study to see whether they have been treated as integrated or segregated. The reason for the inclusion of these two skills as the main concern of this study is that research has supported the view that developments in reading and writing are closely connected (Tierney \& Pearson, 1983; Tierney, Söter, O’Flahavan, \& McGinley (1984); Tierney \& Shanahan (1991). The correlation and regression analyses of the results could also help the researchers to predict the strength and direction of such connections.

The previous scores of a senior group of TEFL students in their reading and writing courses have been collected and defined as general reading and writing test scores. These have been compared with the scores in what we have defined as expository reading and writing test scores (see Method). Based on the results and the literature review, which will follow, the following hypotheses and questions run as:

Research questions:

1. Do Iranian intermediate EFL learners' scores in their reading (reading 1, reading 2, reading 3, and simple prose) and writing skills (grammar 1, grammar 2, advanced grammar, and essay writing) have any correlations in themselves?

2. Do Iranian intermediate EFL learners' scores in their general reading and general writing skills have any correlations in themselves? 
3. Do Iranian intermediate EFL learners' scores in expository reading and writing tests correlate with their general reading and writing scores?

4. Do Iranian intermediate EFL learners perform equally well on general reading, expository reading, general writing and expository writing tests?

Hypotheses:

1. Iranian intermediate EFL learners' scores in reading and writing skills have correlations.

2. Iranian intermediate EFL learners' scores in general reading and writing skills have correlations.

3. Iranian intermediate EFL learners' scores in expository reading and writing tests do not correlate with their general reading and writing scores.

4. Iranian intermediate EFL learners do not perform equally well on general reading, expository reading, general writing and expository writing tests.

\section{LITERATURE REVIEW}

In what follows, the related literature on the importance of integrated approach in general and the content-based language instruction and task-based language instruction in particular, as the two forms of integrated approach, will be discussed.

Tapestry is the metaphorical image suggested by Oxford (2001) for teaching English as a second or foreign language (ESL/EFL). The tapestry is woven from many strands, such as the characteristics of the teacher, the learner, the setting, and the relevant languages. In addition to the four strands, she notes, one of the most crucial of these strands consists of the four primary skills of listening, reading, speaking, and writing. The skill strand of the tapestry leads to optimal ESL/EFL communication when the skills are interwoven during instruction. This is known as the integrated-skill approach or whole language approach. If this weaving together does not occur, the strand consists merely of discrete, segregated skills. This is sometimes known as the segregated-skill approach.

\section{A. Segregated Vs. Integrated Approach}

In the segregated-skill approach, the mastery of discrete language skills such as reading and speaking is seen as the key to successful learning, and language learning is typically separate from content learning (Mohan, 1986). Segregated-skill-oriented courses "have language itself as the focus of instruction to the extent that excessive emphasis on rules and paradigms teaches students a lot about language at the expense of teaching language itself" (Brown, 2000, p. 218). Frequently, segregated-skill ESL/EFL classes present instruction in terms of skill-linked learning strategies: reading strategies, listening strategies, speaking strategies, and writing strategies (Peregoy \& Boyle, 2001).

The philosophy of integrated-skills instruction is based on the concept that in natural, day-to-day experience, oral and written languages are not kept separate and isolated from one another. (Finocchiaro \& Bonomo, 1973; Peregoy \& Boyle, 2001). According to Oxford, Lavine and Crookall (1989), Savignon (1991) and Larsen-Freeman (2000), the principles of CLT emphasize the importance of using a language to communicate in order to learn it. Hymes (1971) stresses that being able to communicate requires more than linguistic competence; it requires communicative competence. Whole language advocates, such as Goodman (1986), Weaver (1990), Edelsky, Altwerger \& Flores (1991), Schwarzer (2001), and Brooks-Harper and Shelton (2003), state that language (oral and written) functions to serve authentic purposes by facilitating meaningful communication. No language process should be separated from the whole teaching task. Harste, Woodward, and Burke (1984) explain that each time someone reads, writes, speaks, or listens, this language encounter feeds into a common data pool. In subsequent encounters with language, the person can draw on this pool. Peregoy and Boyle (2001) suggest that reading and writing as well as speaking and listening should be integral parts of all language classroom activities because all these processes interact with one another.

There are at least two forms of instruction that are clearly oriented toward integrating the skills (Oxford, 2001). They are Content-Based Language Instruction (CBLI) and Task-Based Language Instruction (TBLI).

\section{B. Content-based Language Instruction}

CBLI bases its rationale on the premise that students can effectively obtain both language and subject matter knowledge by receiving content input in the target language. Although it has been recently recognized by authors such as Rodgers as "one of the Communicative Language Teaching spin-off approaches" (2001, p. 2), some authors contemplate the paradigm within an even wider perspective. According to Stryker and Leaver (1997, pp.3-5), for instance, CBLI "is a truly and holistic approach to foreign language education ... (which) can be at once a philosophical orientation, a methodological system, a syllabus design for a single course, or a framework for an entire program of instruction".

Brinton, Snow and Wesche (1989, p. 2) define CBI as "the integration of particular content with language teaching aims, or as the concurrent teaching of academic subject matter and second language skills." According to Eskey (1997, pp. 139-40) "for every piece of content recognized, there is a discourse community which somehow provides us with the means to analyze, talk about, and write about that content".

Documentation on the original foundations of the paradigm can be found from the late eighties in the pioneering works by Mohan (1986), Cantoni-Harvey (1987), Crandall (1987), Benesch (1988), and Brinton et al. (1989) among 
others. Despite its short lived presence in the foreign language teaching arena, now, at the beginning of the twenty first century, there exists a more than abundant literature recently published both in the form of books (Short, 1991; Krueger \& Ryan, 1993; Snow \& Brinton, 1997; Fruhauf, Coyle, \& Christ, 1996; Stryker \& Leaver, 1997; Marsh \& Langé, 1999, 2000; Kasper, 2000a; Haley, 2002, among others), and articles in refereed journals (Crandall, 1994, 2006; Short, 1993, 1994; Gaffield-Vile, 1996; Kasper, 1995, 1997; Sagliano \& Greenfield, 1998; Snow, 1998; Pally \& Bailey, 1999; Dupuy, 2000, among many others).

According to Brinton et al. (1989) and Scarcella \& Oxford (1992), at least three general models of content-based language instruction exist: theme-based (TB), adjunct, and sheltered. "In a theme-based course, the content is exploited and its use is maximized for the teaching of skill areas" (Brinton et al., 1989, p. 26). The TB model integrates the language skills into the study of a theme (e.g., urban violence, cross-cultural differences in marriage practices, natural wonders of the world, or a broad topic such as change). The theme must be very interesting to students and must allow a wide variety of language skills to be practiced, always in the service of communicating about the theme. This is the most useful and widespread form of content-based instruction today and it is found in many innovative ESL and EFL textbooks. Giauque (1987) described a theme-based French course in Greek mythology for third-year university students at Northern Arizona University in the U.S. Klahn (1997) also provides a detailed review of a course for advanced learners of Spanish centered on 'Contemporary Mexican Topics' developed for the School of International and Public Affairs (SIPA) of Columbia University (New York, US).

The adjunct model aims at connecting a specially designed language course with a regular academic course. Adjunct courses are taught to students who are simultaneously enrolled in the regular content course, but who lack the necessary competence to follow the course successfully unless some additional aid is provided. The adjunct courses work therefore as support classes for regular subject matter courses, and offer excellent opportunities to develop the academic strategies necessary to cope with real academic content. Detailed examples of the implementation of the model are provided, among others, in Flowerdew (1993) for teaching biology at a university in the Middle East, and in Iancu (1997) for teaching history and sociology at the George Fox University in Oregon (US).

In the sheltered model, the subject matter is taught in simplified English tailored to students' English proficiency level "A sheltered content-based course is taught in a second language by a content specialist to a group of learners who have been segregated or 'sheltered' from native speakers" (Brinton et al., 1989, p. 15). The term 'sheltered' derives from the model's deliberate separation of second language students from native speakers of the target language for the purpose of content instruction. Studies of this model at the University of Ottawa showed strong student gains in both subject matter and second language skills. These gains were equal to or better than those of comparison groups taking the course in their first language and students in regular French and ESL classes (Edwards, Wesche, Krashen, Clement, \& Kruidenier, 1984; Hauptmann, Wesche \& Ready, 1988). In the sheltered subject-matter instruction, the class is commonly taught by a content instructor, not a language teacher; this content instructor, however, has to be sensitized to the students' language needs and abilities, and has to be familiarized with the traits of the language acquisition process.

Stoller \& Grabe (1997) argue that "practically all instruction is theme-based" (p. 7). They argue that sheltered and adjunct instruction are "not alternatives to theme-based instruction [but] rather...two methods for carrying out themebased instruction. For this reason, [they] see the two terms, content-based instruction and theme-based instruction, as interchangeable" (p. 7). Despite the perceived differences in their orientation and immediate aims, all the models described share the view of language as a medium for learning content, and content as a resource for learning language.

\section{Task-based Language Instruction (TBLI)}

Nunan (1991, p. 279) characterizes TBI as an approach which highlights learning to communicate through interaction in the target language, introducing authentic texts to learning situations, enhancing the learner's own personal experiences, and linking classroom language learning with language activation outside the classroom. TBLI is compatible with a learner-centered educational philosophy (Richards \& Rodgers, 2001; Ellis, 2003, 2005; Nunan, 2004, 2006), consists of particular components such as goal, procedure, specific outcome (Skehan, 1998; Murphy, 2003; Nunan, 2004), and advocates content-oriented meaningful activities rather than linguistic forms (Carless, 2002; Littlewood, 2004).

Task-based language education starts from the basic idea that students learn a language by performing tasks. The central tenet of task-based approach is the task itself. Many people in the related field have defined task from their particular perspectives. Second language acquisition researchers describe tasks in terms of their usefulness for collecting data and eliciting samples of learners' language for research purposes. For example, Bialystok (1983, p. 103) suggests that a communication task must (a) stimulate real communicative exchange, (b) provide incentive for the L2 speaker/learner to convey information, (c) provide control for the information items required for investigation and (d) fulfill the needs to be used for the goals of the experiment. Similarly, Pica (2005) argues that tasks should be developed in such as way to meet criteria for information control, information flow and goals of the study.

Others have looked at tasks from a purely classroom interaction perspective. Some definitions of a classroom task are very specific. For instance, J. Willis (1996, p. 53) defines a classroom task as "a goal-oriented activity in which learners use language to achieve a real outcome." Willis also suggests that language use in tasks is likely to reflect language use in the outside world. Other definitions are more general. Nunan proposes that a communication task "is a piece of classroom work which involves learners in comprehending, manipulating, producing, or interacting in the target 
language while their attention is principally focused on meaning rather than form" (Nunan, 1989, p. 10). Long and Crookes (1991) argue that in addition to being meaning-oriented, classroom tasks must also have a clear relationship with real-world contexts of language use and language need. Skehan (1996a, p. 20) views classroom and L2 research tasks as "activities which have meaning as their primary focus. Success in the task is evaluated in terms of achievement of an outcome, and tasks generally bear some resemblance to real-life language use". Skehan (1998) also represents the core features of tasks within four defining criteria: there is a goal to be worked towards; the activity is outcomeevaluated; meaning is primary; and there is a real-world relationship. Candlin and Murphy (1987) assert that tasks can be effectively organized based on systematic components including goals, input, setting, activities, roles, and feedback. And finally, Ellis (2003, pp. 9-10) lists six "criterial features of a task". He mentions all the aspects listed by Skehan above, and also includes the concept of task as a "workplan for learner activity", which "requires learners to employ cognitive processes", and "can involve any of the four language skills".

In sum, the basic assumptions of TBLI, based on Feez (1998, p. 17), are as follows:

- the focus of instruction is on process rather than product.

- basic elements are purposeful activities and tasks that emphasize communication and meaning.

- learners learn language by interacting communicatively and purposefully while engaged in meaningful activities and tasks.

- activities and tasks can be either:

- those that learners might need to achieve in real life

- those that have a pedagogical purpose specific to the classroom.

- activities and tasks of a task-based syllabus can be sequenced according to difficulty.

- the difficulty of a task depends on a range of factors including the previous experience of the learner, the complexity of the tasks, and the degree of support available.

In line with the principles of an integrated approach, TBLI is a move away from grammar-based approaches where skills are treated as segregated. Armed with insights from SLA research findings and cognitive psychology, attempts have been made at effecting a transition from grammar-based to task-based instruction not just by researchers, but also by language teachers and practitioners (e.g. Bygate, Skehan \& Swain, 2001; Ellis, 2000; Gilabert, 2007; Skehan, 1998, 2003; Oxford, 2006; Robinson \& Gilabert, 2007).

Apart from highly gifted and motivated students, most learners working within a structure-based approach fail to attain a usable level of fluency and proficiency in the second language (L2) even after years of instruction (Skehan, 1996b, p. 18). In India, Prabhu (1987, p. 11) notes that the structure-based courses required "a good deal of remedial reteaching which, in turn, led to similarly unsatisfactory results", with school leavers unable to deploy the English they had been taught, even though many could form grammatically correct sentences in the classroom.

The significance of this debate is that it not only points to the need for more research into this important area in the field of second/foreign language learning and teaching, but also, it brings researchers and language teachers closer together than ever.

As the above review shows, numerous communicative situations in real life involve integrating two or more of the four skills and the user of the language works out his abilities in two or more skills, either simultaneously or in close succession. To see the presence or absence of this segregation of skills we focused on the relationship between writing and reading scores as the main concern of our analysis.

\section{METHOD}

\section{A. Participants}

Based on a language proficiency test and comparison of the students' writing and reading scores, out of 150 senior EFL learners from Azad University of Torbat Heydariye, 95 were chosen and defined as intermediate learners. They were 30 boys and 65 girls aged between 24 and 26. The reason behind the inclusion of the intermediate group was the large sample of this group who were defined based on different scores in their reading and writing courses along with a language proficiency test.

\section{B. Apparatus}

The participants' scores in the related reading and writing courses they had already been evaluated were extracted. The participants' scores in reading 1 (Elementary), reading 2 (intermediate), reading 3 (advanced), and reading simple prose were calculated and defined as general reading scores. The participants' scores in grammar 1 (elementary), grammar 2 (intermediate) advanced writing and essay writing were computed and defined as general writing scores as well. Then, two expository reading and writing tests were administered. The reading comprehension tests were two multiple-choice item tests each having 20 items designed by the researchers. The texts were taken from a book titled 'Patterns', by Lou-Conlin (1998). The participants were required to read the texts carefully and answer the 40 multiplechoice questions within a 60 minute allotted time. The other tests were two expository writing tests. The students were asked to read the writing tasks carefully and write two expository compositions both in English. The allotted time for writing each composition was about one hour. These two reading and writing tests were defined as expository reading 
and expository writing tests. The testing process of reading and writing was held in two successive sessions within a one-week period of time.

\section{Procedure}

First, the participants' responses in the multiple choice reading comprehension tests were scored. Then, based on Engelhard, Gordon, and Gabrielson's (1992) model, the participants' written data were analyzed and scored. This scale consists of five domains: content and organization, style, sentence formation, usage, and mechanics. Two raters assigned points to each of several aspects of participants' writings, providing a rating of the overall quality of the written product as well as ratings on specific elements. The inter-rater reliability between the two raters was .80 (Pearson), which is positive and statistically significant. The overall score of a participant in all types of tests was considered to be 20. Finally, the participants' general reading, general writing, expository reading and expository writing scores were statistically analyzed using the Statistical Package for the Social Sciences (SPSS 16.0).

\section{RESULTS}

As it was pointed out, the students received some scores in their reading 1, reading 2, reading 3 and simple prose and these scores were defined as reading scores. Thus, the reading score was the average of these four scores. The same procedure went for the writing scores. The writing score was the average of grammar 1, grammar 2, advanced grammar, and essay writing scores.

The first question posed was whether Iranian intermediate EFL learners' scores in their reading and writing skills have any correlations in themselves or not and we hypothesized that there is such a correlation. Based on the principles and premises of the whole language approach, the correlation coefficient was used both as a means of describing the strength and the direction of the skills relationships (how closely they are related to each other) and to provide the significance of such relationships. The presence of such correlations was supposed to confirm the fact that teaching the skills, at least reading and writing in our case, has been treated integrativelly.

The results (see Table 1), however, do not reject or prove the first hypothesis completely. Generally, there are some correlations which are positive or negative and in some cases show a significant value. Grammar 1 and grammar 2, for instance, show the highest correlation $(\mathrm{r}=.450)$ with $* * \mathrm{p}<.01$, (Sig. .000) (2-tailed), which is quiet significant. The correlation is also positive. This means that as one variable (grammar 1) increases, the values of the other variable (grammar 2) tend to go in the same direction in a predictable manner. However, the correlation between these two variables, though it is the highest, is not very strong. The scatter plot diagram with the fit line (see Fig. 1) shows this partial relationship.

The weakest correlation goes to reading 1 and reading 3 ( $\mathrm{r}=-.021)$, which is both negative and has no significance value. The scatter plot diagram with the fit line (see Fig. 2) shows that there is no relationship between the two variables. This means that if one variable (reading 1) deceases, so does the other variable (reading 3 ) in a predictable manner. Overall, a look at Table 1 shows that there are no large correlation coefficients among the variables and so there are no strong relationships among the skills except for some cases such as simple prose and advanced grammar among the others. 
TABLE 1

THE CORRELATION COEFFICIENTS AMONG THE SCORES OF READING 1, READING 2, READING 3 AND SIMPLE PROSE AS READING SCORES AND GRAMMAR 1, GRAMMAR 2, ADVANCED GRAMMAR, AND ESSAY WRITING AS WRITING SCORES

\begin{tabular}{|c|c|c|c|c|c|c|c|c|c|}
\hline & & Grammar 1 & Grammar 2 & $\begin{array}{l}\text { Advanced } \\
\text { Grammar }\end{array}$ & \begin{tabular}{|l} 
Essay \\
Writing
\end{tabular} & Reading 1 & Reading 2 & Reading 3 & $\begin{array}{l}\text { Simple } \\
\text { Prose }\end{array}$ \\
\hline \multirow[t]{3}{*}{ Grammar 1} & Pearson Correlation & 1 & $.450^{* * *}$ & $.285^{* *}$ & $.270^{* * *}$ & .096 & -.052 & -.099 & .025 \\
\hline & Sig. (2-tailed) & & .000 & .007 & .010 & .370 & .628 & .355 & .818 \\
\hline & $\mathrm{N}$ & 90 & 90 & 90 & 90 & 90 & 90 & 90 & 90 \\
\hline \multirow[t]{3}{*}{ Grammar 2} & Pearson Correlation & $.450^{* * *}$ & 1 & .111 & .082 & .149 & $-.316^{* *}$ & -.097 & .025 \\
\hline & Sig. (2-tailed) & .000 & & .298 & .444 & .162 & .002 & .365 & .817 \\
\hline & $\mathrm{N}$ & 90 & 90 & 90 & 90 & 90 & 90 & 90 & 90 \\
\hline \multirow{3}{*}{$\begin{array}{l}\text { Advanced } \\
\text { Grammar }\end{array}$} & Pearson Correlation & $.285^{* *}$ & .111 & 1 & .144 & -.060 & -.052 & -.033 & $.377^{* *}$ \\
\hline & Sig. (2-tailed) & .007 & .298 & & .176 & .573 & .626 & .760 & .000 \\
\hline & $\mathrm{N}$ & 90 & 90 & 90 & 90 & 90 & 90 & 90 & 90 \\
\hline \multirow{3}{*}{$\begin{array}{l}\text { Essay } \\
\text { Writing }\end{array}$} & Pearson Correlation & $.270^{* * *}$ & .082 & .144 & 1 & -.122 & -.021 & $.212^{*}$ & -.089 \\
\hline & Sig. (2-tailed) & .010 & .444 & .176 & & .252 & .841 & .045 & .402 \\
\hline & $\mathrm{N}$ & 90 & 90 & 90 & 90 & 90 & 90 & 90 & 90 \\
\hline \multirow[t]{3}{*}{ Reading 1} & Pearson Correlation & .096 & .149 & -.060 & -.122 & 1 & $-.308^{* *}$ & -.018 & .063 \\
\hline & Sig. (2-tailed) & .370 & .162 & .573 & .252 & & .003 & .868 & .558 \\
\hline & $\mathrm{N}$ & 90 & 90 & 90 & 90 & 90 & 90 & 90 & 90 \\
\hline \multirow[t]{3}{*}{ Reading 2} & Pearson Correlation & -.052 & $-.316^{* *}$ & -.052 & -.021 & $-.308^{* *}$ & 1 & .106 & $.227^{*}$ \\
\hline & Sig. (2-tailed) & .628 & .002 & .626 & .841 & .003 & & .322 & .031 \\
\hline & $\mathrm{N}$ & 90 & 90 & 90 & 90 & 90 & 90 & 90 & 90 \\
\hline \multirow[t]{3}{*}{ Reading 3} & Pearson Correlation & -.099 & -.097 & -.033 & $.212^{*}$ & -.018 & .106 & 1 & $-.238^{*}$ \\
\hline & Sig. (2-tailed) & .355 & .365 & .760 & .045 & .868 & .322 & & .024 \\
\hline & $\mathrm{N}$ & 90 & 90 & 90 & 90 & 90 & 90 & 90 & 90 \\
\hline \multirow{3}{*}{$\begin{array}{l}\text { Simple } \\
\text { Prose }\end{array}$} & Pearson Correlation & .025 & .025 & $.377^{* * *}$ & -.089 & .063 & $.227^{*}$ & $-.238^{*}$ & 1 \\
\hline & Sig. (2-tailed) & .818 & .817 & .000 & .402 & .558 & .031 & .024 & \\
\hline & $\mathrm{N}$ & 90 & 90 & 90 & 90 & 90 & 90 & 90 & 90 \\
\hline
\end{tabular}

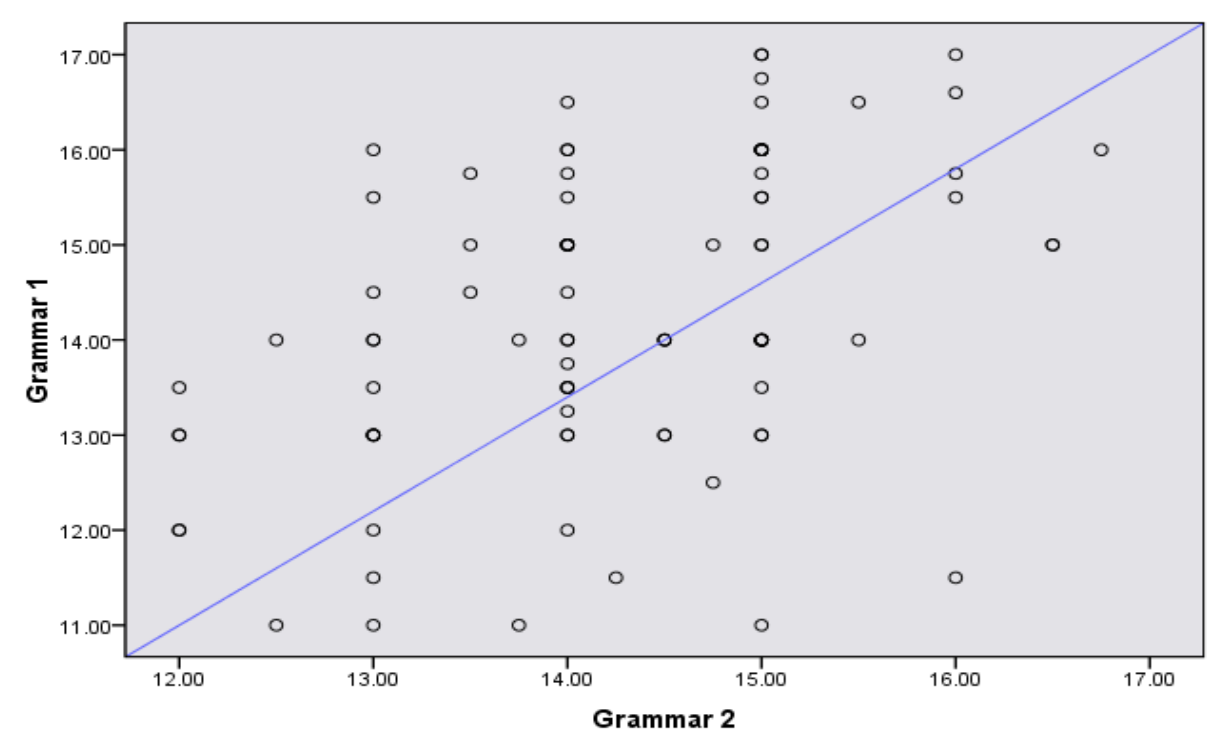

Figure 1 The Scatter Plot Diagram Showing a Partial Relationship between Grammar 1 \& Grammar 2 


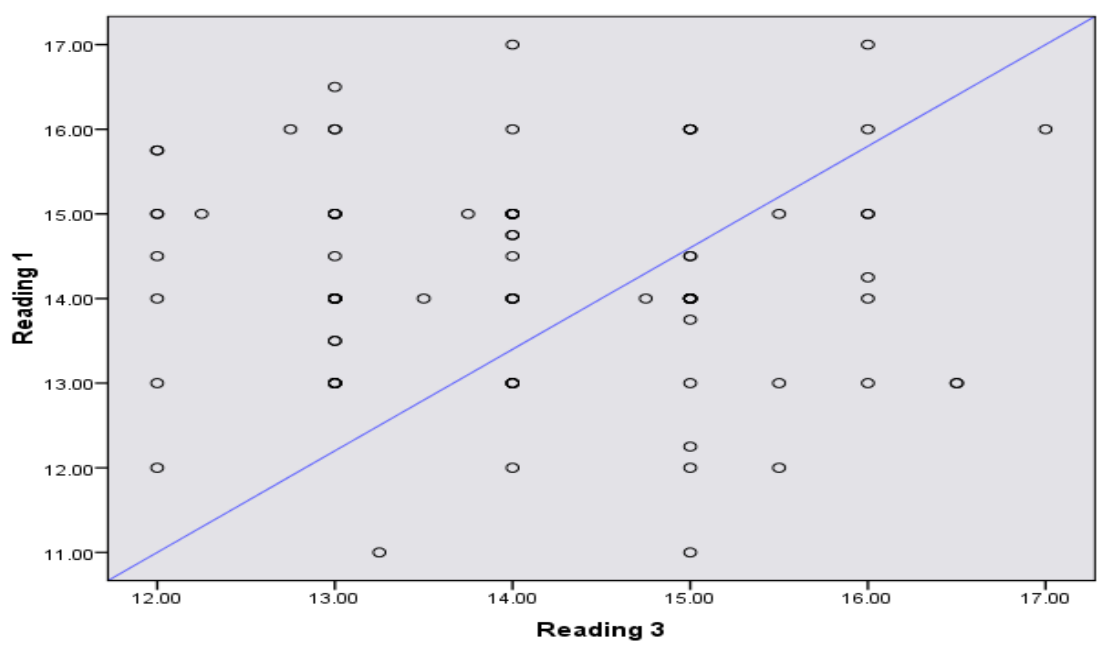

Figure 2 The Scatter Plot Diagram Showining no Correlation between Reading 1 \&

Then, to combine all the reading and writing scores together, and answer the second question of the research, some descriptive, and correlation statistics were run. The simple descriptive statistics (see Table 2) shows that almost all the values of these two skills are the same. The minimum, maximum, and mean of these two variables are all but the same along with the standard deviation which is somehow different (.80336 vs. .62668). The correlation coefficient (see Table 3), however, shows that there is a negative correlation between these two skills ( $\mathrm{r}=-.032$ ), which is not significant. This means that as the direction of this correlation is negative, we cannot predict the strength of relationship between general reading and writing. Moreover, the scatter plot diagram (see Fig. 3) also supports this negative relationship and therefore, the second hypothesis is rejected meaning that there is no relationship between the skills of reading and writing.

TABLE 2

DESCRIPTIVE STATISTICS FOR SKILLS OF GENERAL WRITING \& GENERAL READING

\begin{tabular}{|l|l|l|l|l|l|}
\hline & $\mathrm{N}$ & Minimum & Maximum & Mean & Std. Deviation \\
\hline General Writing & 90.00 & 12.12 & 15.88 & 14.1767 & .80336 \\
\hline General Reading & 90.00 & 13.12 & 15.88 & 14.1042 & .62668 \\
\hline Valid N (listwise) & 90.00 & \multicolumn{5}{|l}{} \\
\hline
\end{tabular}

TABLE 3

THE CORRELATION COEFFICIENTS BETWEEN GENERAL WRITING \& GENERAL READING SCORES

\begin{tabular}{|l|l|l|l|}
\hline \multicolumn{2}{|l|}{} & General Writing & General Reading \\
\hline General Writing & Pearson Correlation & 1 & -.032 \\
& Sig. (2-tailed) & & .765 \\
& N & 90 & 90 \\
\hline General Reading & Pearson Correlation & -.032 & 1 \\
& Sig. (2-tailed) & .765 & \\
& N & 90 & 90 \\
\hline
\end{tabular}

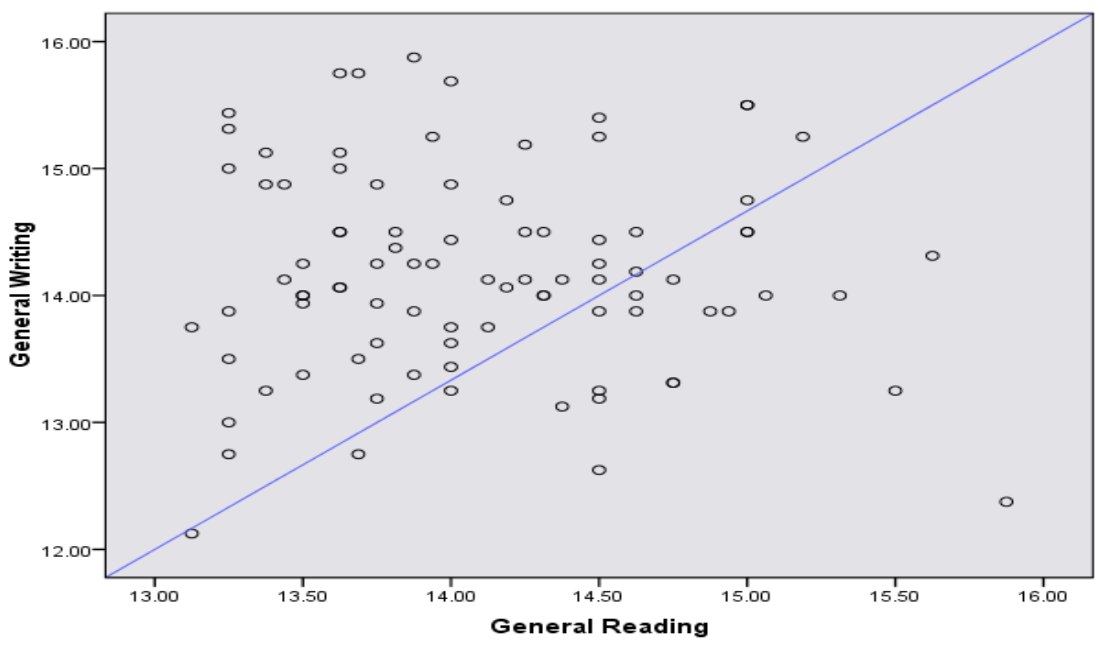

Figure 3 The Scatter Plot Diagram Showing Negative Correlation between General Writing \& ... 
The third question of the research was whether Iranian intermediate EFL learners' scores in expository reading and writing tests correlate with their general reading and writing scores or not. It was hypothesized that there is no such a correlation. The result (Table 4) shows that almost all the correlations are negative and they are all significant. It means that we cannot predict the score in one variable on the basis of another score in another variable.

TABLE 4

THE CORRELATION COEFFICIENTS AMONG GENERAL WRITING, GENERAL READING, EXPOSITORY WRITING \& EXPOSITORY READING SCORES

\begin{tabular}{|c|c|c|c|c|c|}
\hline & & General Writing & General Reading & Expository Writing & Expository Reading \\
\hline \multirow[t]{3}{*}{ General Writing } & Pearson Correlation & 1 & -.032 & -.025 & .037 \\
\hline & Sig. (2-tailed) & & .765 & .812 & .726 \\
\hline & $\mathrm{N}$ & 90 & 90 & 90 & 90 \\
\hline \multirow[t]{3}{*}{ General Reading } & Pearson Correlation & -.032 & 1 & -.167 & -.075 \\
\hline & Sig. (2-tailed) & .765 & & .116 & .485 \\
\hline & $\mathrm{N}$ & 90 & 90 & 90 & 90 \\
\hline \multirow[t]{3}{*}{ Expository Writing } & Pearson Correlation & -.025 & -.167 & 1 & -.162 \\
\hline & Sig. (2-tailed) & .812 & .116 & & .127 \\
\hline & $\mathrm{N}$ & 90 & 90 & 90 & 90 \\
\hline \multirow[t]{3}{*}{ Expository Reading } & Pearson Correlation & .037 & -.075 & -.162 & 1 \\
\hline & Sig. (2-tailed) & .726 & .485 & .127 & \\
\hline & $\mathrm{N}$ & 90 & 90 & 90 & 90 \\
\hline
\end{tabular}

And to answer the fourth question of the research, the repeated measures of ANOVA were run. The question was whether Iranian intermediate EFL learners perform equally well on general writing, general reading, expository writing and expository reading tests and we hypothesized that they do not perform equally well on these skills. The skills defined as factors 1 to 4 in Table 5 are general writing, general reading, expository writing and expository reading respectively. The results of the post hoc tests mostly confirmed the null hypothesis meaning that there were some significant differences among the performance of the learners in the related skills. As the pairwise comparisons show (see Table 5), there are significant differences among factors 1 and 3,1 and 4, 2 and 3,2 and 4, and finally 3 and 4 with $\mathrm{p}<.05$, (Sig. .000). Among these skills, general writing and general reading do not show a significant difference. The mean difference (see Table 6) between these two skills is also almost the same (14.177 vs. 14.104). This shows that the EFL learners have been able to perform almost equally well on these two skills. But, with expository writing and expository reading texts the performance is quite different (see Tables $5 \& 6$ ).

TABLE 5

PAIRWISE COMPARISONS OF GENERAL WRITING, GENERAL READING, EXPOSITORY WRITING AND EXPOSITORY READING TESTS

\begin{tabular}{|c|c|c|c|c|c|c|}
\hline \multirow[b]{3}{*}{ Factor 1} & \multirow[b]{3}{*}{ (J) Factor 1} & \multirow[b]{3}{*}{ Mean Difference (I-J) } & \multirow[b]{3}{*}{ Std. Error } & \multirow[b]{3}{*}{ Sig. ${ }^{a}$} & \multirow{2}{*}{\multicolumn{2}{|c|}{ 95\% Confidence Interval for Difference a }} \\
\hline & & & & & & \\
\hline & & & & & Lower Bound & Upper Bound \\
\hline \multirow[t]{3}{*}{1} & 2 & .073 & .109 & 1.000 & -.222 & .367 \\
\hline & 3 & $2.516^{*}$ & .131 & .000 & 2.163 & 2.868 \\
\hline & 4 & $1.377^{*}$ & .120 & .000 & 1.053 & 1.700 \\
\hline \multirow[t]{3}{*}{2} & 1 & -.073 & .109 & 1.000 & -.367 & .222 \\
\hline & 3 & $2.443^{*}$ & .126 & .000 & 2.102 & 2.784 \\
\hline & 4 & $1.304^{*}$ & .114 & .000 & .997 & 1.611 \\
\hline \multirow[t]{3}{*}{3} & 1 & $-2.516^{*}$ & .131 & .000 & -2.868 & -2.163 \\
\hline & 2 & $-2.443^{*}$ & .126 & .000 & -2.784 & -2.102 \\
\hline & 4 & $-1.139^{*}$ & .141 & .000 & -1.520 & -.757 \\
\hline \multirow[t]{3}{*}{4} & 1 & $-1.377^{*}$ & .120 & .000 & -1.700 & -1.053 \\
\hline & 2 & $-1.304^{*}$ & .114 & .000 & -1.611 & -.997 \\
\hline & 3 & $1.139^{*}$ & .141 & .000 & .757 & 1.520 \\
\hline
\end{tabular}

$*$. The mean difference is significant at the .05 level. 
TABLE 6

THE ESTIMATES OF GENERAL WRITING, GENERAL READING, EXPOSITORY WRITING AND EXPOSITORY READING AS SHOWN AS 1 TO 4 RESPECTIVELY

\begin{tabular}{|l|l|l|l|l|}
\hline \multirow{2}{*}{ Factor 1 } & \multirow{3}{*}{ Mean } & \multirow{3}{*}{ Std. Error } & \multicolumn{2}{|l|}{ 95\% Confidence Interval } \\
\cline { 4 - 5 } & 14.177 & .085 & 14.008 & 14.345 \\
\hline 1 & 14.104 & .066 & 13.973 & 14.235 \\
\hline 3 & 11.661 & .097 & 11.468 & 11.855 \\
\hline 4 & 12.800 & .088 & 12.625 & 12.975 \\
\hline
\end{tabular}

\section{DISCUSSION \& CONCLUSION}

Dismantling language into different skills which goes to the traditional era of structuralism in linguistics and behaviorism in psychology is a facilitating need in pedagogy, but finding the underlying construct of these so-called skills is a complicated issue. In regard to the existence of correlation, grammar 1 and grammar 2 were happened to have at least a partial correlation. They are both defined as grammar and the prediction is that if the score in one skill increases, the score in the other skill or variable increases for that matter. The same is true for the construct of reading but from a different perspective. Reading 1 and reading 2 as two skills sharing the same underlying construct as reading comprehension were seen to experience the weakest correlation and the interpretation is that if the score in one variable (reading 1) deceases, so does the other variable (reading 3) in a predictable manner. But it seems that when we look at all the variables (skills), we see a fluctuation among the scores (reading and writing in our case) which may be due to the way these skills are treated. It seems that the emphasis given to each variable is different, which may be due to different methods used by different teachers, the textbooks used, the educational priority taken by policy makers and syllabus designers locally and internationally, and the difference among the learners themselves. When skills are treated in a dismantled way, the result is that the learners' performance in one skill is going to be better than another skill, as reading and writing in our case. But, comparing just two variables and interpreting the result with a small population is not concluding the presence or absence of the integration approach. We, therefore, combined all the variables of reading comprehension together and defined them as general reading and we did the same for general writing. This time the integrative approach was supported and there was correlation between these scores. But, if we change the nature of the variables or increase the number of subjects we may come to different results and interpretation. This shows, on the one hand, the difficulty of the skills construct and the influence of the external factors such as learners, teachers, among the other variables on the other hand.

Linked to the above interpretation is the concept of language proficiency itself. In our study, we have separated a group of learners and categorised them as intermediate and less proficient in comparison to advanced levels. Language proficiency, however, seems to be considered as a relative concept. Stern (1983, p. 46), for instance, describes L2 proficiency, as comprising the intuitive mastery of the forms of the language, the intuitive mastery of the linguistic, cognitive, affective, and sociocultural meanings expressed by the language forms, the capacity to use the language with maximum attention to communication and minimum attention to form, and the creativity of language use. Accordingly, it can then be concluded that the use of language in a number of specific ways is difficult even for native speakers of a particular language. Comparing the advanced group may also lead to other results.

The next illuminating point to discuss is that as these learners have been defined as intermediate learners, the prediction was that they will not be able to respond to expository texts without difficulty. This may be explained from the perspective of the nature of expository texts. In working with such texts one need to analyze information and information analysis is a cognitive demanding task. In Drury's words, "the activity of analyzing the information means that writers must distance themselves from the content more than the activities of observation, description and classification which result in a typical factual, report genre. Such distancing develops a more abstract genre which is removed from its real-world experiential content" (2001, p. 110). In addition, expository texts are characterized by the use of specialized lexicon (related to the topic involved) and by an argumentative structure that requires information ordering that always is related to the topic and the writers' communicative intentions: definition or description of an event, explanation of its origin, description of types or categories involved in a concept, etc. (Boscolo, 1996). We need, therefore, even more advanced learners to handle such texts. These intermediate learners had difficulty in handling such texts and this proves the validity of previous studies in that expository texts are more difficult for less proficient learners. In handling such texts these learners proved that they are still intermediate and their scores in working with such texts were not the same with the scores they had taken in general reading and writing courses. In other words, their scores from the expository tests had no correlation or relationship with the scores in their general reading and writing scores in their related English courses.

The conclusion and the generalizability of such findings should be treated with more caution. With more variables and a larger sample we may have more reliable conclusions. As pointed out, the metaphorical image suggested by Oxford (2001) and advocated in this study is woven from many strands, such as the characteristics of the teacher, the learner, the setting, and the relevant languages. In addition to the four strands, one of the most crucial of these strands 
consists of the four primary skills of listening, reading, speaking, and writing. The effect of speaking and listening along with other strands should also be investigated.

Another point is that levels of proficiency and the learning context should be considered as well. The relationship among the four skills should be tested in elementary and advanced levels with different age groups, backgrounds, needs, interests and abilities and this should be tested in different foreign and second language contexts with various syllabuses and resources that they may follow or make use of.

In line with other researchers, these researchers suggest that reading and writing along with other skills and parameters should be integral parts of all language classroom activities because all these processes interact with one another. Selecting an integrated approach in teaching language whereby all variables work together helps learners develop communicative competence and through the developing of competences, they will be more conscious about their own learning, identifying strengths and weaknesses to be improved. Becoming aware will lead them to take a course of action and make their own decisions about their own learning process, which is, finally, the goal of any language learning process.

It is much better to make the teaching and learning situation come closer to the way we do things in real life to make classes more challenging, motivating and meaningful for the learners of English as a second or foreign language. In line with the integrated approach possible tasks are suggested to help learners learn language by interacting communicatively and purposefully while engaged in meaningful activities.

Finally, it should be asserted that applying the integrated approach calls for professional teachers who are creative and dynamic. Applying an integrated approach is in line with the latest findings in the field of linguistics and there is certainly a need for more research in this area. This study may help language teachers to revisit and revise their syllabus in terms of the skills whether they teach them interwoven with other skills or there is sometimes a mismatch between these skills. The study may shed some light on syllabus designers and policy makers to design textbooks with a taskbased view which hinder the segregation of skills.

\section{ACKNOWLEDGEMENTS}

We are deeply grateful of a senior group of EFL students from Azad University of Torbat Heydariye who patiently took part in this experiment.

\section{REFERENCES}

[1] Benesch, S. (Ed.) (1988). Ending remediation: Linking ESL and content in higher education. Washington DC: TESOL.

[2] Bialystok, E. (1983). Some factors in the selection and implementation of communication strategies. In C. Faerch and G. Kasper (Eds.), Strategies in interlanguage communication (pp.100 -118). London: Longman.

[3] Boscolo, P. (1996). The use of information in expository text writing. In C. Pontecorvo, M. Orsolini, B. Burge, \& L. Resnick. (Eds.), Children's early text construction (pp. 219-230). New Jersey: Lawrence Erlbaum.

[4] Brinton, D, Snow, M, and Wesche, M. (1989). Content-based second language instruction. New York: Newbury House.

[5] Brooks-Harper, G. and Shelton, P. W. (2003). Revisiting whole language development: A transactional approach to learning. Research for Educational Reform, 81, 35-42.

[6] Brown, H. D. (2000). Teaching by principles. USA: Pearson ESL.

[7] Bygate, M. Skehan, P. and Swain, M. (Eds) (2001). Researching pedagogic tasks: Second language learning, teaching, and testing. Harlow: Longman.

[8] Candlin, C., and Murphy, D. (1987). Language learning tasks (Eds.). Englewood Cliffs, N.J.: Prentice Hall International.

[9] Cantoni-Harvey, G. (1987). Content-area language instruction: Approaches and strategies. Reading, MA: Addison-Wesley.

[10] Carless, D. (2002). Implementing task-based learning with young learners. ELT Journal, 56, 389-396.

[11] Crandall, J. (Ed.) (1987). ESL through content-area instruction. Englewood Cliffs, NJ: Prentice Hall.

[12] Crandall (1994). Content-centered language learning. ERIC Digest (EDO-FL-94-06).

[13] Crandall, J. A. (2006, March). The power of writing: The importance of writing in EFL. Presented at the annual conference of TESOL Arabia: Dubai, UAE.

[14] Drury, H. (2001). Short answers in first-year undergraduate science writing. What kind of genres are they? In M. Hewings (Ed.), Academic writing in context: Implications and applications: Papers in honor of Tony Dudley Evans (pp.104-122). London: Birmingham University Press.

[15] Dupuy, B. C. (2000). Content-based instruction: Can it help ease the transition from beginning to advanced foreign language classes? Foreign Language Annals, 33, 205-222.

[16] Edelsky, C., Altwerger, B., and Flores, B. (1991). What's whole language: What's the difference. Portsmouth, NH: Heinemann.

[17] Edwards, H. P., Wesche, M.B., Krashen, S., Clement, R., and Kruidenier, B. (1984). Second language acquisition through subject matter learning: A study of sheltered psychology classes at the University of Ottawa. Canadian Modern Language Review, 41, 268-282.

[18] Ellis, R. (2000). Task-based research and language pedagogy. Language Teaching Research, 4, 193-220.

[19] Ellis, R. (2003). Task-based language learning and teaching. Oxford: Oxford University Press.

[20] Ellis, R. (2005). Planning and task performance in a second language. Amsterdam: John Benjamin Publishing Company.

[21] Eskey, D. E. (1997). Syllabus design in content-based instruction. In M. A. Snow \& D. A. Brinton (Eds.), The content-based classroom: Perspectives on integrating language and content (pp. 132-141). White Plains, NY: Longman.

[22] Finocchiaro, M. \& Bonomo, M. (1973). The foreign language learner. New York: Regents Publishing Comp Inc.

[23] Feez, S. (1998). Text-based syllabus design Sydney: National Center for English Teaching and Research. 
[24] Flowerdew, J. (1993). An educational or process approach to the teaching of professional genres. ELT Journal, 47, 305-316.

[25] Fruhauf, G., Coyle, D., and Christ, I. (Eds.) (1996). Teaching content in a foreign language: Practice and perspective in European bilingual education. Alkmaar: Stichting Europrint.

[26] Gaffield-Vile, N. (1996). Content-based second language instruction at the tertiary level. ELT Journal, 50, 108-114.

[27] Giauque, G. (1987). Teaching for content in a skills course: Greek mythology in French. Foreign Language Annals, 20, 565569.

[28] Gilabert, R. (2007). Effects of manipulating task complexity on self-repair during L2 oral performance. IRAL, 45, 215-240.

[29] Goodman, K. (1986). What's whole in whole language. Portsmouth, NH: Heinemann.

[30] Haley, M. H. (2002). An interactive approach to content-based second language learning. Boston, MA: Allyn \& Bacon.

[31] Harste, J., Woodward, V. and Burke, C. (1984). Language stories and literacy lessons. Portmouth, NH: Heinemann.

[32] Hauptmann, P., Wesche, C., Boo, M., and Ready, P. (1988). Second language acquisition through subject matter learning: A follow-up study at the University of Ottawa. Language Learning, 38, 439-482.

[33] Hymes, D. H. (1971). On communicative competence. Philadelphia: University of Pennsylvania Press.

[34] Iancu, M. (1997). Adapting the adjunct model: A case study. In M.A. Snow \& D.M. Brinton, (Eds.), The content-based classroom: Perspectives on Integrating Language and Content (pp. 149-157). White Plains, NJ: Addison Wesley Longman.

[35] Kasper, L. (1995). Theory and practice in content-based ESL reading instruction. English for Specific Purposes, 14, $223-230$.

[36] Kasper, L. (1997). The impact of content-based instructional programs on the academic progress of ESL students. English for Specific Purposes, 16, 309-320.

[37] Kasper, L. (2000a). Content-based college ESL instruction. Mahwah, NJ: Lawrence Erlbaum Associates.

[38] Klahn, N. (1997). Teaching for communicative and cultural competence: Spanish through contemporary Mexican topics. In S. B. Stryker and B. L. Leaver (Eds.), Content-based instruction in foreign language education (pp. 202-218). Washington D.C.: Georgetown University Press.

[39] Krashen, S. (1993). The power of reading. Englewood, CO: Libraries Unlimited.

[40] Krueger, M. and F. Ryan (Eds.) (1993). Language and content: Discipline and content-based approaches to language study. Lexington, MA: DC Heath.

[41] Larsen-Freeman, D. (2000) Techniques and principles in language teaching. 2nd ed. Oxford: Oxford University Press.

[42] Littlewood, W. (2004). The task-based approach: Some questions and suggestions. ELT Journal, 58, 319-326.

[43] Long. M. \& Crookes, G. (1991). Three approaches to task-based syllabus design. TESOL Quarterly, 26, 27-55.

[44] Lou-Conlin, M. (1998). Patterns: A short prose reader (Fifth Edition). Boston. New York.

[45] Marsh, D., and G., Langé (Eds.) (1999). Implementing content and language integrated learning. A research-driven TIE-CLIL foundation course reader. Jyväskyla: University of Jyväskyla.

[46] Marsh, D. and G. Langé (Eds.) (2000). Using languages to learn and learning to use languages. Jyväskyla: University of Jyväskyla.

[47] Mohan, B. (1986). Language and content. Reading, MA: Addison-Wesley.

[48] Murphy, J. (2003). Task-based learning: The interaction between tasks and learners. ELT Journal, 57, 352-360.

[49] Nunan, D. (1989). Designing tasks for the communicative classroom. Cambridge, UK: Cambridge University Press.

[50] Nunan, D. (1991). Communicative tasks and the language curriculum. TESOL Quarterly, 25, 279-295.

[51] Nunan, D. (2004). Task-based language teaching. Cambridge: Cambridge University Press.

[52] Nunan, D. (2006). Task-based language teaching in the Asia context: Defining 'task'. Asian EFL Journal, 8(3), A-1. http://www.asian-efl-journal.com/April_09_dn.php (accessed 28/6/2010)

[53] Oxford, R. (1990). Language learning strategies: What every teacher should know. Boston: Wadsworth Publishing Company.

[54] Oxford, R. (2001). Integrated skills in the ESL/EFL classroom. ERIC Digest. Washington, DC: ERIC Clearinghouse on Languages and Linguistics. (ERIC Reproduction Service No. ED 456670).

[55] Oxford, R. L. (2006). Task-based language teaching and learning: An overview. Asian EFL Journal, 8(3), A-5. http://www.asian-efl-journal.com/April_09_ro.php (accessed 15/9/2010)

[56] Oxford, R., Lavine, R. Z. and Crookall, D. (1989). Language learning strategies, the communicative approach, and their classroom implication. Foreign Language Annuals, 22, 29-39.

[57] Pally, M. and Bailey, N. (Eds.) (1999). Sustained content teaching in academic ESL/EFL: A practical approach. New York: Houghton Mifflin.

[58] Peregoy, S. F. and Boyle, O. F. (2001). Reading, writing, and learning in ESL: A resource book for K-12 teachers. New York: Addison Wesley Longman, Inc.

[59] Pica, T. (2005). Classroom learning, teaching, and research: A task-based perspective. The Modern Language Journal, 3, 339352.

[60] Prabhu, N. S. (1987). Second language pedagogy. Oxford: Oxford University Press

[61] Richards, J. C. and Rodgers, T. S. (2001). Approaches and methods in language teaching. 2nd ed. Cambridge: Cambridge University Press.

[62] Robinson, P. and Gilabert, R. (2007). Task complexity, the cognition hypothesis and second language learning and performance. IRAL, 45, 161-176.

[63] Rodgers, T. S. (2001). Language teaching methodology. ERIC Digest. http://www.cal.org/ericcll/digest/rodgers. html.

[64] Sagliano, M. and Greenfield, K. (1998). A collaborative model of content-based EFL instruction in the liberal arts. TESOL Journal, 7, 3-28.

[65] Savignon (1991). Communicative learning teaching: State of the art. TESOL Quarterly, 25, 261-277.

[66] Scarcella, R., and Oxford, R. (1992). The tapestry of language learning: The individual in the communicative classroom. Boston: Heinle \& Heinle.

[67] Schwarzer, D. (2001). Whole language in a foreign language class: From theory to practice. Foreign Language Annals, 34, 5259. 
[68] Short, D. (1991). How to integrate language and content instruction: A training manual. Washington DC: Center for Applied Linguistics.

[69] Short, D. (1993). Assessing integrated language and content instruction. TESOL Quarterly, 27, 627-656.

[70] Short, D. (1994). Expanding middle school horizons: Integrating language, culture, and social studies. TESOL Quarterly, 28, 581-608.

[71] Skehan, P. (1996a). A framework for the implementation of task based instruction. Applied Linguistics, 17, 38-62.

[72] Skehan, P. (1996b). Second language acquisition research and task-based instruction. In J. Willis and D. Willis (Eds.), Challenge and change in language teaching (pp. 17-30). Oxford: Heinemann.

[73] Skehan, P. (1998). A cognitive approach to language learning. Oxford: Oxford University Press.

[74] Skehan, P. (2003). Tasks in L2 learning and teaching. Language Teaching, 36, 1-14.

[75] Snow, M. A. (1998). Trends and issues in content-based instruction. Annual Review of Applied Linguistics, 18, 243-267.

[76] Snow, M. A. and D. Brinton (Eds.) (1997). The Content-based classroom: Perspectives on integrating language and content. White Plains, NY: Addison Wesley-Longman.

[77] Stern, H. H. (1983). Fundamental concepts of language teaching. Oxford: Oxford University Press.

[78] Stoller, F. and W. Grabe (1997). A Six T's approach to content-based instruction. In M. A. Snow and D. Brinton (Eds.), The content-based classroom: Perspectives on integrating language and content. White Plains, NY: Addison Wesley-Longman.

[79] Stryker, S. N. and B. L. Leaver (Eds.) (1997). Content-based instruction in foreign language education. Washington D.C.: Georgetown University Press.

[80] Tierney, R. J., Söter, A., O'Flahavan, J. O. and McGinley, W. (1984). The effects of reading and writing upon thinking critically. Reading Research Quarterly, 24, 134-173

[81] Tierney, R. J., and Pearson P. D. (1983). Toward a composing model of reading. Language Arts, 60, 569-580

[82] Tierney, R. J., and Shanahan, T. (1991). Research on the reading-writing relationship: Interactions, transactions, and outcomes. In R. Barr, M. L. Kamil, P. Mosenthal, and P. D. Pearson (Eds.), Handbook of reading research (pp. 246-280), New York: Longman.

[83] Weaver, C. (1990). Understanding whole language: From principles to practice. Portsmouth, NH: Heinemann.

[84] Willis, J. (1996). A framework for task-based learning. London: Longman.

Javad Nabizadeh Moghadam is an instructor in Azad University of Torbat Heydariye at the English department. He got his MA in Translation from Tehran University, Iran. His main research interests are language teaching, translation and ancient language studies.

Seyyed Mohammad Reza Adel is a Ph.D. candidate in Ferdowsi University of Mashhad, Iran. His main research interests are: Discourse analysis, Psycholinguistics and Critical education. 